\title{
TAF9 wt Allele
}

National Cancer Institute

\section{Source}

National Cancer Institute. TAF9 wt Allele. NCI Thesaurus. Code C52613.

Human TAF9 wild-type allele is located within 5q11.2-q13.1 and is approximately $19 \mathrm{~kb}$ in length. This allele, which encodes transcription initiation factor TFIID subunit 9 protein, is involved in the mediation of the activity of the transcriptional initiation complex. 